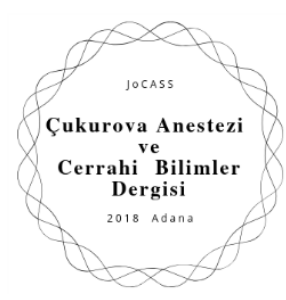

\title{
COMPARISON OF THE RESULTS OF MINI-PERCUTANEOUS NEPHROLITHOTOMY PERFORMED WITH DIFFERENT SHEATH-SIZES IN PRESCHOOL-AGED CHILDREN

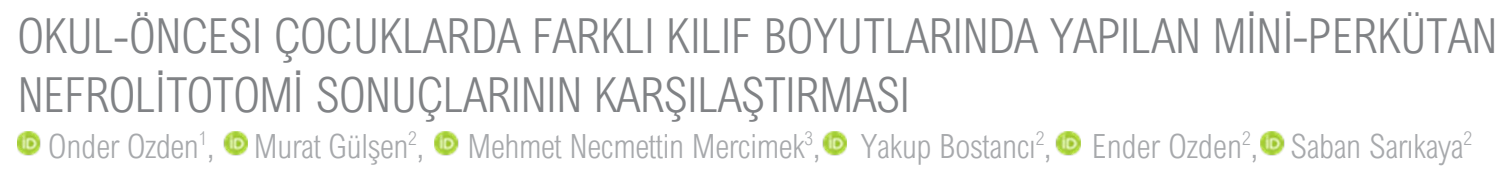

1 Cukurova University, Department of Pediatric Surgery, Adana, Turkey

2 Ondokuz Mayıs University, Department of Urology, Samsun, Turkey

3 Liv Hospital Samsun, Department of Urology, Samsun, Turkey

Sorumlu Yazar/Corresponding Author: Onder Ozden E-mail: onder24@hotmail.com

Geliş Tarihi/Received: 22.08.2020 Kabul Tarihi-Accepted: 30.08.2020 Available Online Date/Çevrimiçi Yayın Tarihi: 31.08.2020

Cite this article as: Ozden O, Gülşen M, Bostancı Y, Ozden E, Sarıkaya S. Comparison of The Results of Mini-Percutaneous Nephrolithotomy Performed with Different Sheath-sizes in Preschool-aged Children. J Cukurova Anesth Surg. 2020:3(2);69-78.

Doi: 10.36516/jocass.2020.41

\section{$\ddot{O} z$}

Amaç: $\mathrm{Bu}$ çalışmada, bebeklerde ve okul öncesi yaş gruplarındaki çocuklarda uygulanan mini perkütan nefrolitotomi (Mini-PCNL)'nin başarı oranını ve komplikasyonları; kompleks böbrek taşları için iki farklı kanal kılıfı boyutuna göre karşılaştırmayı amaçladık.

Materyal ve Metot: Ocak 2002 ile Haziran 2018 tarihleri arasında mini-PCNL uygulanan 7 yaşından küçük 260 pediatrik hastanın kayıtları geriye dönük olarak araştırıldı. Karmaşık böbrek taşı hastalığı olan 149 okul öncesi çocuk ve bebek ( $66 \mathrm{kız}$ ve 83 erkek) çalışmaya dahil edildi. Çalışmada toplam 158 mini-PCNL gerçekleştirildi ve hastalar kanal kılıfı boyutuna göre iki farklı gruba ayrıldı (14Fr grubu, $n=104 ; \% 69.8 ; 20 \mathrm{Fr}$ grubu, $\mathrm{n}=45 ; \% 30.2$ ). Bulgular: Ortalama hasta yaşı $14 \mathrm{Fr}$ ve $20 \mathrm{Fr}$ gruplarında sırasıyla $3.5 \pm 2.0$ ve $5.2 \pm 2.2$ yıl idi $(\mathrm{p}=0.158)$. Hemoglobin seviyesindeki azalma $(0.73 \mathrm{gr} / \mathrm{dL} ; 1.0 \mathrm{gr} / \mathrm{dL}, \mathrm{p}=<0.041)$, kan transfüzyon oranı (\% 3.6; \% 16.7, p $=0.013)$, floroskopi süresi $(4.29 \mathrm{dk} ; 5.42 \mathrm{dk}, \mathrm{p}=<0,001)$, dakikada ortalama parçalanan taş boyutu (4.29 mm2 / $\mathrm{dk} ; 5.43 \mathrm{~mm} 2 / \mathrm{dk}, \mathrm{p}=0,016)$, ameliyat süresi (65.2 dk; $74.1 \mathrm{dk}, \mathrm{p}=0.040)$, kateter çıkarılma süresi (2.58 gün; 2.89 gün, $\mathrm{p}=<0.001$ ) ve hastanede kalış süreleri (3.78 gün; 4.67 gün, $\mathrm{p}=0.010$ ) açısından 14Fr grubu 20Fr grubuna göre anlamlı düşük düzeylere sahipti. Bununla birlikte, cinsiyet, taşın lateralitesi, yeri, yükü ve opaklığ1, hidronefroz varlığı, önceki taş tedavisi sayısı, giriş sayısı, kaliksler, taş temizleme oranı, diversiyon tipleri, komplikasyonlar ve taşsızlık oranları açısından gruplar arasında istatistiksel bir farklılık gözlenmedi.

Sonuçlar: $\mathrm{Bu}$ çalışma, okul öncesi çocuklarda ve bebeklerde, 14Fr ile 20Fr kılıfla yapılan mini-PCNL prosedürlerinde 14Fr kılıf boyutunun; hemoglobin seviyesindeki azalma, kan transfüzyon oranı, kateter çıkarma süresi ve hastanede kalış süresi açısından önemli avantajlara sahip olduğunu ve komplikasyon ve taşsızlık oranları açısından ise herhangi bir üstünlüğü olmadığını göstermiştir.

Anahtar kelimeler: Çocuk, endoüroloji, perkütan nefrolitotomi. 


\begin{abstract}
Aim: In this study, we aimed to compare the success rate and complications of mini percutaneous nephrolithotomy (Mini-PCNL) applied in infants and children in pre-school age groups; in accordance two different tracts sheath sizes for complex kidney stones.

Materials and Methods: Two hundred sixty pediatric patients younger than 7 years old who had undergone miniPCNL between January 2002 and June 2018 were evaluated retrospectively. 149 preschool children and infants (66 girls and 83 boys) with complex kidney stone disease were included in the study. A total of 158 mini-PCNLs were performed in the study, and patients were divided into two groups according to tract sheath size (14Fr group, $\mathrm{n}=104 ; 69.8 \% ; 20 \mathrm{Fr}$ group, $\mathrm{n}=45 ; 30.2 \%$ ).

Results: The mean age of the patients was $3.5 \pm 2.0$ and $5.2 \pm 2.2$ years in the $14 \mathrm{Fr}$ and $20 \mathrm{Fr}$ groups, respectively $(\mathrm{p}=0.158)$. Decrease in hemoglobin level (respectively, $0.73 \mathrm{gr} / \mathrm{dL} ; 1.0 \mathrm{gr} / \mathrm{dL}, \mathrm{p}=<0.041$ ), blood transfusion rate (respectively, 3.6\%; 16.7\%, p = 0.013), fluoroscopy time (respectively, $4.29 \mathrm{~min} ; 5.42 \mathrm{~min}, \mathrm{p}=<0.001$ ), average stone size per minute (respectively, $4.29 \mathrm{~mm} 2 / \mathrm{min} ; 5.43 \mathrm{~mm} 2 / \mathrm{min}, \mathrm{p}=0.016$ ), operation time (respectively, $65.2 \mathrm{~min} ; 74.1 \mathrm{~min}, \mathrm{p}=0.040$ ), catheter removal time (respectively, 2.58 days; 2.89 days, $\mathrm{p}=$ $<0.001$ ) and the length of hospital stay (respectively, 3.78 days; 4.67 days, $p=0.010$ ), the $14 \mathrm{Fr}$ group had significantly lower levels than the $20 \mathrm{Fr}$ group. However, no statistical difference was observed between the groups in terms of gender, laterality, location, burden and opacity of the stone, presence of hydronephrosis, number of previous stone treatments, number of access, calyxes, stone removal rate, types of diversion, complications, and stone-free rates.

Conclusions: In this study, in preschool children and infants, in mini-PCNL procedures performed with $14 \mathrm{Fr}$ and $20 \mathrm{Fr}$ sheath, 14Fr sheath size has important advantages in terms of decrease in hemoglobin level, blood transfusion rate, catheter removal time and hospital stay, and it showed that it has no superiority in terms of complication and stone-free rates.
\end{abstract}

Keywords: Children, endourology, percutaneous nephrolithotomy.

\section{Introduction}

Pediatric urolithiasis is a serious health issue. This issue especially influences toddlers in developing countries. It is a challenge to operate because of the smallness of the urinary system and the probability of recurrence ${ }^{1}$. Also, the incidence of urolithiasis increased dramatically (raising 6\% per year) among children in the developed countries over years ${ }^{2}$. Therefore, pediatric urolithiasis is a serious health problem for developing and developed countries.

After manuscript reported by Woodside et al. ${ }^{3}$ in 1985 , the treatment of the pediatric stone disease has rapidly evolved, and PCNL has accepted as a generally minimal invasive procedure in children likewise in adults. Nonetheless, PCNL with standard methods and equipment could have difficulty in pediatric patients with complex kidney stone disease in consequence of the smallness of urinary tract and collecting system, kidney mobility of the children and, fragile renal parenchyma $^{4}$. A mini-PCNL was first described in pediatric patients by Jackman et al. ${ }^{5}$, by using smaller sized equipment to decrease morbidity and complications of standard PCNL. The mini-PCNL has many advantages with disadvantages, and the most important disadvantages may be a lack of algorithm in use. Moreover, the other disadvantages are the rarer incidence of pediatric kidney stone in pediatric patient than adults and insufficient information about the safety and effectiveness of newer techniques. 
Even though evidence of benefit lacks, most pediatric urologists are inspired to use smaller instruments in children. In our study, we criticized the results of minipercutaneous nephrolithotomy (miniPCNL) by comparing two differently sized tracts (14Fr vs. 20Fr) in children with complex kidney stone disease to discuss this approach.

\section{Materials and Methods}

A total of 158 mini-PCNL were performed in 149 infants and preschool-aged children (bilateral in 9 patients) with complex kidney stones from January 2002 to June 2018. Complex calculi were defined as either staghorn or those with a stone bulk larger than $300 \mathrm{~mm}^{2}$, involving more than one calyx and the upper ureter ${ }^{6}$. The stone burden was calculated by multiplying of the two-dimensional length of the stones in millimeters. The total stone burden was found by the sum of each stone's areas in the case of multiple stones. Preoperatively, patients were evaluated by urine analysis, urine culture, serum creatinine, other routine blood tests, abdominal and pelvic ultrasonography, abdominal X-ray evaluating especially the kidneys, ureters, and bladder (KUB) and intravenous pyelography. Renal scintigraphy and computerized tomography were examined when required. A primary metabolic evaluation was performed in all patients.

All procedures were performed under general anesthesia with parenteral antibiotic prophylaxis. The patients with urinary tract infections received appropriate antibiotic treatment preoperatively. The procedure started in the lithotomy position with catheterization of ureter with an open-ended 5Fr soft catheter via cystoscopy. Percutaneous access was gained in all cases under guide of fluoroscopy using an 18-gauge access needle in the prone position. A 0.035 -inch diameter floppy-tipped hydrophilic guidewire was entered into the renal pelvis. Tract dilation was done by fascial dilators in the $14 \mathrm{Fr}$ group, and then a $14 \mathrm{Fr}$ renal sheath was placed following dilation. In the 20Fr group, the tract was dilated gradually by using Amplatz dilators (Boston Scientific), and a 20Fr working sheath was placed.

Children were grouped as the 14Fr group and the 20Fr group in pursuant of the size of the tract. A total of 158 renal units were operated. A 9.5/12Fr pediatric cystourethroscope was used via a $14 \mathrm{Fr}$ tract in 112 cases constituting Group 1. A $17 \mathrm{Fr}$ pediatric nephroscope (Karl Storz) was used via a $20 \mathrm{Fr}$ tract in 46 cases constituting Group 2. An antegrade 7.5Fr flexible ureteroscope (Karl Storz) or 16Fr flexible cysto-urethroscope (Olympus, Tokyo, Japan) were used if the stones could not be reached by the rigid instruments. Lithotripsy was performed by a Holmium: YAG laser. Stone fragments were either irrigated out through the sheath or cleared out by zero-tip nitinol basket catheter and grasping forceps. Residual stone fragments were assessed by fluoroscopic images. After stone vaporization and collection of fragments, a 12 Fr re-entry nephrostomy tube was left in the renal pelvis, and antegrade pyelography was worked to evaluate renal pelvis and ureter.

The all patients were followed up for postoperative complications. On the day of surgery, patients were assessed with a complete blood count to determine hemoglobin $(\mathrm{Hb})$ drop. The need for blood transfusion was contingent upon evidence of perioperative bleeding, $\mathrm{Hb}$ decline, and findings of anemia. X-ray of KUB was performed to confirm stone-free status on the postoperative day (POD) 1. Ultrasonography was preferred for radiological evaluation in patients with radiolucent stone. The stone-free rate was defined as the nonappearance of visible stone on X-ray of KUB. 
In nephrostomized cases, a nephrostogram was routinely obtained on POD 2, then if the patient was stone-free and no-sign of extravasation and a free flow of contrast medium was visualized into the bladder, nephrostomy tube was removed. Ureteral stent was stayed in until the urinary drainage was normal. Each patient was further observed for any postoperative complications. Patients were discharged if they were comfortable, afebrile with clear urine, and not leaking from the nephrostomy site.

Number and location of access points, operative time, fluoroscopy time, $\mathrm{Hb}$ drop, blood transfusion, hospitalization time, stone clearance, and complications were recorded, and the procedures were evaluated according to these parameters. Complications of the procedure were assessed by modified Clavien's classification ${ }^{7}$. Patients' data were introduced into a database prospectively.

The two groups were analyzed regarding patient and stone characteristics, together with postoperative findings Statistical package of the social sciences (SPSS). Data were noted as the number and percentage or mean and standard deviation. Continuous variables were analyzed using Mann-Whitney $U$ test to compare two means. Comparison of the categorical data between groups was performed using the Chi-square test. $P$ values $<0.05$ were considered significant.

\section{Results}

Overall, 158 mini-PCNL procedures were conducted in 149 infants and preschoolaged children ( 66 girls and 83 boys) with complex kidney stones. Nine of these children had undergone surgery as a separate session for each kidney. None of children performed a conversion to open surgery or secondary PCNL operation. We did not have to delay operation in the groups due to bleeding or similar problems. Five patients had upper ureteral stones in addition to kidney stones, which were removed by an antegrade approach using a flexible scope. Four children had distal ureteral stone, which was also treated using retrograde ureteroscopic lithotripsy in a single session with miniPCNL. In another patient, in addition to kidney stone, there was also a $20 \mathrm{~mm}$ bladder stone which was removed by percutaneous lithotripsy and a mini-PCNL was performed to the right kidney at the same session. A comparative summary of patients' demographic data and preoperative characteristics for both groups were summarized in Table 1 . The mean patient ages of the $14 \mathrm{Fr}$ and $20 \mathrm{Fr}$ groups were $3.5 \pm 2.0$ years and $5.2 \pm 2.2$ years, respectively $(\mathrm{p}<0.001)$. The calculated mean stone burden was statistically significantly different between the groups; it was smaller in the 14Fr group $\left(261 \mathrm{~mm}^{2}\right.$ versus $403 \mathrm{~mm}^{2}$ ). Both groups were comparable in terms of gender, laterality of the stone, previous stone treatment history, stone location, opacity, and hydronephrosis status. Perioperative and post-operative findings were shown in Table 2. One access was enough for almost all patients. Only two cases in the $14 \mathrm{Fr}$ group and three in $20 \mathrm{Fr}$ group needed two accesses. Operative time of the $14 \mathrm{Fr}$ series was shorter than that of $20 \mathrm{Fr}$ group (65.2 $\mathrm{min}, 74.1 \mathrm{~min}$, respectively $\mathrm{p}$ $=0.040)$. Mean stone burden was significantly lower in $14 \mathrm{Fr}$ group (261 $\mathrm{mm}^{2}, 403 \mathrm{~mm}^{2}$ respectively, $\left.\mathrm{p}=0.015\right)$. Fluoroscopy time was found to be lower in the $14 \mathrm{Fr}$ group $(3.8 \mathrm{~min}$ vs. $5.0 \mathrm{~min}$ $\mathrm{p}<0.001$ ). Stone clearance rate (stone size/surgery time) did not be found statistically in between the groups. Intraoperative complications were similar in the two groups. However, there was an advantage for $14 \mathrm{Fr}$ group over $20 \mathrm{Fr}$ group in terms of significant reduction of $\mathrm{Hb}$ $\operatorname{drop}(0.73 \mathrm{~g} / \mathrm{dL}$ vs. $1.0 \mathrm{~g} / \mathrm{dL}, \mathrm{p}=0.041)$ and blood transfusion rates $(3.6 \%$ vs. $16.7 \%$, $\mathrm{p}=0.013)$. 
Table 1 Patients' demographics and preoperative characteristics

\begin{tabular}{|c|c|c|c|}
\hline Parameter & $\begin{array}{c}\text { Group } 1 \\
\text { (14Fr) }\end{array}$ & $\begin{array}{c}\text { Group } 2 \\
(20 \mathrm{Fr})\end{array}$ & $\mathbf{p}$ \\
\hline Number of patients $(\%)$ & $104(69.8)$ & $45(30.2)$ & \\
\hline No. renal units & 112 & 46 & \\
\hline Gender (girl/boy), n & $50 / 54$ & $16 / 29$ & 0.158 \\
\hline Mean age, years & $3.5 \pm 2.0$ & $5.2 \pm 2.2$ & $<0.001$ \\
\hline Laterality (right/left), n & $44 / 59$ & $19 / 25$ & 0.859 \\
\hline Mean stone burden, $\mathrm{mm}^{2}$ & $261 \pm 240.7$ & $403 \pm 422.6$ & 0.015 \\
\hline Previous stone treatment, $\mathrm{n}(\%)$ & & & 0.416 \\
\hline$S W L$ & $2(1.9)$ & $3(6.7)$ & \\
\hline$P N L$ & $1(1.0)$ & 0 & \\
\hline Open surgery & 0 & $1(2.2)$ & \\
\hline Preoperative urine culture, n (\%) & & & 0.005 \\
\hline Infected & $10(10.1)$ & $13(30.2)$ & \\
\hline Not infected & $89(89.9)$ & $930(69.9)$ & \\
\hline Stone location $\mathrm{n}(\%)$ : & & & 0.179 \\
\hline Pelvis & $50(45.5)$ & $10(22.7)$ & \\
\hline Lower pole & $17(15.5)$ & $8(18.2)$ & \\
\hline Upper pole & $5(4.5)$ & $1(2.3)$ & \\
\hline Pelvis + polar & $28(25.5)$ & 17 (38.6) & \\
\hline Upper ureter & $3(2.7)$ & $2(4.5)$ & \\
\hline Staghorn & $6(5.5)$ & $5(11.4)$ & \\
\hline Semistaghorn & $1(0.9)$ & $1(4.5)$ & \\
\hline Opacity, n (\%) & & & 0.101 \\
\hline Opaque & 105 (93.8) & $42(95.5)$ & \\
\hline Nonopaque & $17(6.2)$ & $2(4.5)$ & \\
\hline Hydronephrosis, n (\%) & & & 0.065 \\
\hline Yes & $39(34.8)$ & $24(52.2)$ & \\
\hline No & $73(65.2)$ & $22(47.8)$ & \\
\hline
\end{tabular}

SWL: Shock wave lithotripsy, PVL: Penile venous ligation 
One child had an indwelling ureteral stent in 14Fr group and one in 20Fr group. There was one patient who required double-J stenting due to an impacted upper ureteral stone in the 14Fr group; the remainder had $12 \mathrm{Fr}$ nephrostomy tubes. The mean catheter removal time was significantly shorter in $14 \mathrm{Fr}$ group $(2.58$ days, 2.89 days, respectively $\mathrm{p}<0.001$ ). Hospitalization time for 14Fr group was lower than that required for 20Fr group (3.78 days vs. 4.67 days, $p=0.010$ ).

There was neither a significant complication nor a death in our series. Complication rates were not found to be statistically significant in the groups. Overall, 147 of 158 renal units were stonefree with a single mini-PCNL session (96.4\% in $14 \mathrm{Fr}$ group and $91.3 \%$ in $20 \mathrm{Fr}$ group, $\mathrm{p}=0.182$ ).

\section{Discussion}

Evaluation and treatment of urolithiasis in children is dramatically unlike from that in adults and usually requires special instruments. In earlier, urologists were hesitant to perform PCNL in children due to concerns about the use of large equipment in pediatric patient and the risk of major complications. During the past two decades, with the advances in technique and equipment used, operative treatment of urolithiasis in children has evolved efficaciously and PCNL, which is a well-established technique in adults, has become the standard procedure in this age group. Recently published manuscripts about pediatric PCNL have reported the use of adult sized equipments, with acceptable success and complication rates $^{3,8}$. Since Jackman et al. ${ }^{5}$ and Helal et al. ${ }^{9}$ described the technique of mini-PCNL in children, urologists have been inspired to perform with smaller equipment.
Although the term mini-PCNL is not clearly defined, that may mean the practice with smaller diameter nephroscopes than standard PCNL; a technique utilizing a tract size of $20 \mathrm{Fr}$ or less can be categorized as mini-PCNL. Although in earlier, it was thought to be performed for small sized stones, nowadays many urologists have performed mini-PCNL even for large and complex stones with a reasonable clearance rate and faster recovery ${ }^{10}$. The optimum technique is still developing with the aim to perform in the smallest track as well as that allows for best stone clearance rate with minimal complication. The miniPCNL in adult patients is debated, but it is the accepted and common procedure for nephrolithiasis in children ${ }^{11}$.

In the literature, there is confusion about the classification of PCNL. Generally accepted PCNL classification according to the sheath size consists of the mini PCNL (14-20 Fr), the ultra mini PCNL (9-13 Fr), and the micro PCNL (4.85 Fr). On the other hand, there are studies using different named classifications but with the same sheath size ${ }^{12}$. In this study, we did research on sheath differences within the miniPCNL group and found significant differences between $14 \mathrm{Fr}$ and $20 \mathrm{Fr}$ even though they were within the same classification. Wright at al. ${ }^{13}$ advised that PCNL should be sub-classified according to positioning, sheath size, fragmentation method, and postoperative drainage. This study supports that this sheath classification is inadequate.

Although there are some manuscripts in the literature about the performing of adult versus pediatric instrumentation in pediatric $\mathrm{PCNL}^{6,14,15}$, the reports regarding use of mini-PCNL especially in young children with complex stones are rare $^{16-19}$. The presented study aimed to evaluate morbidity and success rates according to the tract sizes in infants and 
preschool-aged children who had undergone mini-PCNL for complex renal calculi.

Table 2 Operative Data

\begin{tabular}{|c|c|c|c|}
\hline Parameter & $\begin{array}{c}\text { Group } 1 \\
\text { (14Fr) }\end{array}$ & $\begin{array}{c}\text { Group } 2 \\
\text { (20Fr) }\end{array}$ & $\mathbf{p}$ \\
\hline No. access & $1.04 \pm 0.2$ & $1.08 \pm 0,2$ & 0.289 \\
\hline \multicolumn{4}{|l|}{ Calix accessed } \\
\hline Upper calyceal & 5 & 2 & \multirow{3}{*}{0.426} \\
\hline Middle calyceal & 37 & 9 & \\
\hline Lower calyceal & 64 & 31 & \\
\hline Mean operative time, min & $65.2 \pm 29.9$ & $74.1 \pm 31.4$ & 0.040 \\
\hline Mean fragmented stone size in per minute, $\mathrm{mm}^{2} / \mathrm{min}$ & $4.29 \pm 3.95$ & $5.42 \pm 4.53$ & 0.016 \\
\hline Flouroscopy time, min & $3.8 \pm 2.8$ & $5.0 \pm 2.7$ & $<0.001$ \\
\hline Hemoglobin drop, g/dL & $0.73 \pm 0.70$ & $1.0 \pm 0.88$ & 0.041 \\
\hline Blood transfusion, $\mathrm{n}(\%)$ & $3(3.6)$ & $6(16.7)$ & 0.013 \\
\hline \multicolumn{4}{|l|}{ Diversion, $\mathrm{n}(\%)$} \\
\hline Nephrostomy & $105(93.8)$ & $42(91.3)$ & 0.583 \\
\hline Tubeless & $7(6.2)$ & $4(8.7)$ & \\
\hline \multicolumn{4}{|l|}{ Complications, } \\
\hline None & $101(90.2)$ & $37(80.4)$ & \\
\hline Clavien 1 & $1(0.9)$ & $3(6.5)$ & 0.063 \\
\hline Clavien 2 & $7(6.2)$ & $2(4.3)$ & \\
\hline Clavien 3 & $3(2.7)$ & $4(8.7)$ & \\
\hline Mean catheter removal, day & $2.58 \pm 1.9$ & $2.89 \pm 0.9$ & $<0.001$ \\
\hline Length of hospital stay, day & $3.78 \pm 3.6$ & $4.67 \pm 3.8$ & 0.010 \\
\hline Stone free rate, $\mathrm{n}(\%)$ & $105(96.4)$ & $42(91.3)$ & 0.182 \\
\hline
\end{tabular}

Theoretically, larger diameter of device for the percutaneous tract consequences more parenchymal and vascular injury in smaller kidney. There is a $51 \%$ reduction in renal parenchymal volume that is dilated by the $14 \mathrm{Fr}$ sheath compared to the 20Fr sheath. Although Webb and Fitzpatrick $^{20}$ showed that properly placed 
dilation to sizes equivalent to $50 \mathrm{~F}$ in an adult. The concept might be considered as "smaller the percutaneous tract caliber, less trauma caused on renal parenchyma of a growing child, thus less invasiveness in general." Furthermore, the lessen diameter of tract dilation has advantage for possible damage such as a renal infundibular calyceal injury ${ }^{21}$. In a prospective study, several authors reported apparently less hematocrit drop while performing miniPCNL utilizing a tract less than $20 \mathrm{Fr}^{15,22,23}$. In our study, the $14 \mathrm{Fr}$ group revealed to be more advantageous over $20 \mathrm{Fr}$ group regarding the significant reduction of $\mathrm{Hb}$ drop $(0.73$ vs. $1.35 \mathrm{~g} / \mathrm{dL}$, $\mathrm{p}=0.01$ ) and $3.8 \%$ of patients in $14 \mathrm{Fr}$ and $27.8 \%$ of patients in $20 \mathrm{Fr}$ sheath group had applied blood transfusions $(p=0.023)$. These findings clearly show the minimal invasiveness of the 14Fr dilation group.

Performing smaller instruments also may decline the torque forces applied to the kidney with instruments. A longer instrument exerts a larger force on the kidney, because of the lever principle ${ }^{14}$. Aron et al. ${ }^{18}$ reported that torqueing a rigid nephroscope is the only most important provoker of hemorrhages during PCNL. We used flexible ureteroscope and cystourethroscope for locations that could not be arrived by using the rigid instruments in both groups. Flexible instruments can not only reduce transfusion rates but can also increase stone-free rates by decreasing the use of extra access and, also diminishing of the torque affect consequenced by rigid instruments. Another important factor for severe bleeding during PCNL is improper puncture of the collecting system.

The mean catheter removal and hospitalization times in our series were significantly lower in $14 \mathrm{Fr}$ group than in the $20 \mathrm{Fr}$ group (2.5 days, 2.7 days, $\mathrm{p}=0.042$ and 3.8 days, 4.7 days, $\mathrm{p}=0.033$, respectively). We think that small-sized tract procedure would result in less urinary leak and would obviously likely to result in less hospital stay.

The clearance rate is the most crucial variables regarding treatment procedure for nephrolithiasis. The stone-free rate in our study was $92.3 \%$ in $14 \mathrm{Fr}$ and $72.2 \%$ in $20 \mathrm{Fr}$ group $(\mathrm{p}=0.073)$ after PCNL monotherapy with acceptable morbidity. With auxiliary procedures, it increased to $96.1 \%$ in $14 \mathrm{Fr}$ group and $83.3 \%$ in $20 \mathrm{Fr}$ group. These results supported the literature within range of $68 \%-100 \% \%^{1,24}$. Higher stone-free rates may be due to the lower stone burden in the 14Fr group.

PCNL is not without complications ${ }^{25}$. As we classified the complications in agreement with modified Clavien's system, we noticed grade 1 complications in one (fever), grade 2 complications in two (postoperative fever requiring antibiotic treatment), grade $3 \mathrm{a}$ in one (hydrothorax, managed conservatively with a chest tube) and grade $3 b$ in four (prolonged urinary leakage requiring a double-J stent) patients. All the complications were managed successfully, and patients were discharged without any problems. In our cohort, the intraoperative complications were comparable in the two groups. We did not experience any significant complications such as visceral injuries or sepsis.

The most critical drawback of mini-PCNL is the duration of the operation. Reasons for the observed difference might be diminished intraoperative field visibility, the need for fragmentation by laser into very small stones, and the small sheath. In our experience, visibility was not a major issue regarding the duration of the operation. Visibility is hardly an issue if the access is perfect and minimal visualization difficulties were easily overcome using retrograde irrigation through the ureteral catheter, which also facilitated spontaneous removal of small stone fragments within the system via the 
sheath. In our study, the operative time of the 20Fr group was higher than that of the $14 \mathrm{Fr}$ group $(85.5 \mathrm{~min}$ vs. $75.6 \mathrm{~min}$, $\mathrm{p}=0.140$ ). The increased operative time in the 20Fr group might be related to the insignificant but higher stone burden and prolonged intracorporeal lithotripsy time required by the Holmium laser. However, there was no significant difference regarding the stone clearance rate (stone size/surgery time) between the two groups.

The limitations of this study included the retrospective nature of the study, together with the restricted number of patients. In the future, prospectively organized, randomized, and controlled studies having larger sample sizes may give us a valid conclusion in this respect and thus, may help to conclude which modality is better.

\section{Conclusion}

If performed by skilled and experienced hands, the mini-PCNL technique using $14 \mathrm{Fr}$ is a feasible and effective method for best stone clearance achievement in the management for complex renal calculi in children. It is hard to define which access is optimal for which cases. Nonetheless, we observed that tract dilation was one of the essential factors in reducing blood loss and hospital stay. Also, we may say that it has superiority to reduce dilation to the minimum size necessary for efficient stone removal, and the most appropriately sized instruments should be used to minimize the complication rate. We may say that the mini-PCNL technique with 14Fr should be considered as a standard procedure for children, especially in infants and preschool-aged children with complex kidney stones requiring PCNL.

\section{Conflict of Interest}

The authors declare that they have no conflict of interest

\section{Funding}

None

References

1. Rizvi SA, Naqvi SA, Hussain $Z$, et al. Management of pediatric urolithiasis in Pakistan: experience with 1,440 children. J Urol. 2003; 169: 634-7.

2. Dwyer ME, Krambeck AE, Bergstralh EJ, et al. Temporal trends in incidence of kidney stones among children: a 25-year population based study. J Urol. 2012; 188: 247-52.

3. Woodside JR, Stevens GF, Stark GL, et al. Percutaneous stone removal in children. $\mathrm{J}$ Urol. 1985; 134: 1166-7.

4. Kapoor R, Solanki F, Singhania P, et al. Safety and efficacy of percutaneous nephrolithotomy in the pediatric population. J Endourol. 2008; 22: 637-40.

5. Jackman SV, Hedican SP, Peters CA, et al. Percutaneous nephrolithotomy in infants and preschool age children: experience with a new technique. Urology. 1998; 52: 697-701.

6. Ozden E, Sahin A, Tan B, et al. Percutaneous renal surgery in children with complex stones. J Pediatr Urol. 2008; 4: 295-8.

7. Dindo D, Demartines $\mathrm{N}$ and Clavien PA. Classification of surgical complications: a new proposal with evaluation in a cohort of 6336 patients and results of a survey. Ann Surg. 2004; 240: 205-13.

8. Mor Y, Elmasry YE, Kellett MJ, et al. The role of percutaneous nephrolithotomy in the management of pediatric renal calculi. J Urol. 1997; 158: 1319-21. 
9. Helal M, Black T, Lockhart J and Figueroa TE. The Hickman peel-away sheath: alternative for pediatric percutaneous nephrolithotomy. J Endourol. 1997; 11: 171-2.

10. Sabnis RB, Ganesamoni R and Sarpal R. Miniperc: what is its current status? Curr Opin Urol. 2012; 22: 129-33.

11. EAU Guidelines. Edn. presented at the EAU Annual Congress Barcelona 2019. ISBN 978-94-92671-04-2. http://uroweb.org/guidelines/compilationsof-all-guidelines/.

12. Zanetti SP, Talso M, Palmisano F, et al. Comparison among the available stone treatment techniques from the first European Association of Urology Section of Urolithiasis (EULIS) Survey: Do we have a Queen? PLoS One. 2018; 13: e0205159.

13. Wright AE, Somani BK and Rukin NJ. Proposition for new terminologies in PCNL: what does 'ultra-mini-micro' actually mean? Urolithiasis. 2014; 42: 53940.

14. Bilen CY, Kocak B, Kitirci G, et al. Percutaneous nephrolithotomy in children: lessons learned in 5 years at a single institution. J Urol. 2007; 177: 1867-71.

15. Guven S, Istanbulluoglu O, Ozturk A, et al. Percutaneous nephrolithotomy is highly efficient and safe in infants and children under 3 years of age. Urol Int. 2010; 85: 455-60.

16. Unsal A, Resorlu B, Kara C, et al. Safety and efficacy of percutaneous nephrolithotomy in infants, preschool age, and older children with different sizes of instruments. Urology. 2010; 76: 247-52.
17. Mahmud $\mathrm{M}$ and Zaidi Z. Percutaneous nephrolithotomy in children before school age: experience of a Pakistani centre. BJU Int. 2004; 94: 1352-4.

18. Aron M, Yadav R, Goel $\mathrm{R}$, et al. Percutaneous nephrolithotomy for complete staghorn calculi in preschool children. J Endourol. 2005; 19: 968-72.

19. Manohar T, Ganpule AP, Shrivastav P, et al. Percutaneous nephrolithotomy for complex caliceal calculi and staghorn stones in children less than 5 years of age. $\mathrm{J}$ Endourol. 2006; 20: 547-51.

20. Webb DR and Fitzpatrick JM. Percutaneous nephrolithotripsy: a functional and morphological study. J Urol. 1985; 134: 587-91.

21. Clayman RV, Surya V, Hunter D, et al. Renal vascular complications associated with the percutaneous removal of renal calculi. J Urol. 1984; 132: 228-30.

22. Mishra S, Sharma R, Garg C, et al. Prospective comparative study of miniperc and standard PNL for treatment of 1 to $2 \mathrm{~cm}$ size renal stone. BJU Int. 2011; 108: 896-9.

23. Cheng F, Yu W, Zhang X, et al. Minimally invasive tract in percutaneous nephrolithotomy for renal stones. $\mathbf{J}$ Endourol. 2010; 24: 1579-82.

24. Desai M. Endoscopic management of stones in children. Curr Opin Urol. 2005; 15: 107-12.

25. Ozden E, Mercimek MN, Yakupoglu YK, et al. Modified Clavien classification in percutaneous nephrolithotomy: assessment of complications in children. J Urol. 2011; 185: 264-8. 